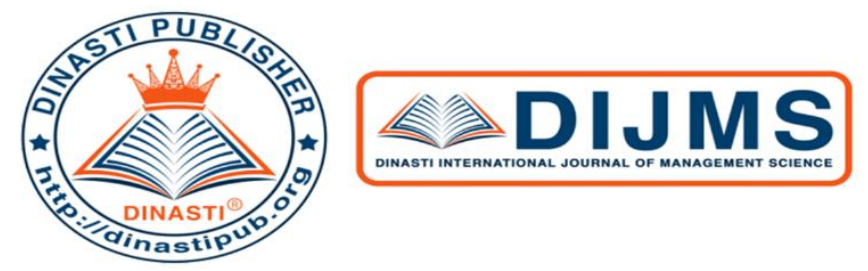

$+6281387654578$

+6281387654578 (Q)

https://dinastipub.org/DIJMS (4)

dinasti-info@gmail.com G.

\title{
THE INFLUENCE OF WORK MOTIVATION, WORK DISCIPLINE ON EMPLOYEE PERFORMANCE (CASE STUDY AT MERANGIN REGENCY SETTLEMENT AREA OFFICE EMPLOYEES)
}

\author{
Mardalena $^{1}$, Sarinah ${ }^{2}$, Endang Solichin ${ }^{3}$ \\ 1) Economic Education Study Program STKIP YPM, Merangin, Indonesia \\ ${ }^{2)}$ Economic Education Study Program STKIP YPM, Merangin, Indonesia \\ ${ }^{3)}$ Economic Education Study Program STKIP YPM, Merangin, Indonesia
}

\begin{tabular}{|c|c|}
\hline $\begin{array}{l}\text { Corresponding author: first author } \\
\text { E-mail: } \\
\text { mardalena@stkipypmbangko.ac.id } \\
\frac{\text { sarinahrina584@ gmail.com }}{\text { solend27@yahoo.com }} \\
\end{array}$ & $\begin{array}{l}\text { Abstract: This research aims to determine the effect of } \\
\text { work motivation and work discipline on employee } \\
\text { performance partially and simultaneously at the same } \\
\text { time. The type of research used is explanatory research } \\
\text { with a quantitative approach. The sample of this study } \\
\text { were employees at the Merangin Regency } \\
\text { Resettlement Area Office. Number of sample were } 80 \\
\text { person. Data obtained by distributing questionnaires. } \\
\text { The data analysis technique used in this study is } \\
\text { multiple linear regression analysis, using the } \mathrm{F} \text { test and } \\
\mathrm{T} \text { test. The results of multiple linear regression } \mathrm{Y}= \\
79.21+0.41 \mathrm{X} 1+0.74 \mathrm{X} 2+\text { e. Meanwhile the results } \\
\text { of the T test of work motivation variables on employee } \\
\text { performance are } \mathrm{t} \text { count } \geq \mathrm{t} \text { table or } 3.31 \geq 1.99 \text {. while, } \\
\text { work discipline variable on employee performance } \\
\text { was t count } \geq \mathrm{t} \text { table or } 5.02 \geq 1.99 \text {. The coefficient of } \\
\text { determination ( }{ }^{2} \text { ) is } 0.34 \% \text {. This means that } 34 \% \text { of } \\
\text { the variation in performance can be predicted by work } \\
\text { motivation and work discipline variables. While } 65 \% \\
\text { can be predicted by other variables. } \\
\text { Keywords: Work Motivation, Work Discipline, Work } \\
\text { Perfomance. }\end{array}$ \\
\hline
\end{tabular}

\section{INTRODUCTION}

Human resources (HR) become one of the main aspects in the running of an organization. Good HR management, will facilitate the organization in achieving its objectives. This is because the organizational members will then carry out all the missions and activities planned by the organization. The implementation of duties and work is an obligation for every member who is incorporated in an organization, both in government and private organizations. Members in carrying out these tasks and work in order to achieve 
organizational goals. These goals become the main targets that become a reference for each member who has been determined by the governing body of a particular organization. So, all activities carried out are certain that everything leads to the achievement of the goals of the organization. So it is not uncommon for that, the organization in addition to setting goals then then hand in hand also sets a variety of rules. This is of course due to all activities carried out by each member in accordance with what is expected for the effectiveness of achieving goals.

This rule is made with the intention that each component of the organization carries out its duties in accordance with the stated objectives. In an effort to achieve the goals of the organization, various aspects are needed, some important aspects are discipline and work motivation. Discipline and motivation itself can arise and grow by themselves from within the members of the organization and can also be caused due to encouragement from the leadership of the organization.

Discipline is also an important thing in the organization, because in carrying out every activity or daily activities. Work discipline is very necessary for employees to meet the rules set by the company. Efforts to provide discipline are basically an effort to improve employee performance at the agency.

Work motivation is important in increasing a work effectiveness, because people who have high work motivation will try hard to get their work done as well as possible. This is similar to the results of previous research conducted by Annisa Pratiwi and Ismi Darmastuti (2014), which concluded that motivation and work discipline affect employee performance. Furthermore, Masasti Suci and Ismiyati (2015) in their research results concluded that work discipline gave the greatest influence on employee performance, followed by other variables namely motivation and office layout.

In line with the results of the above research, Ade Wahyudi, et al (2012) have conducted research in organizations in the form of schools. Where the respondents are the teachers as members of the school organization. The results of their study concluded that work discipline, work motivation and supervision of school principals were able to improve teacher performance.

\section{LITERATURE REVIEW Work Motivation}

Motivation is related to effort and encouragement arising from within oneself which is done to fulfill one's goals. So it can be understood that motivation is able to encourage organizational members or employees to work. Hasibuan (2007:141), work motivation is an encouragement that can direct subordinates to work productively to realize the goals that have been determined.

According to Abdul Hakim in Annisa Pratiwi (2014) it is said that one of the factors that influence employee performance is motivation. Where motivation is able to move someone to try to do something in achieving the desired goals. Furthermore Rivai (2011:844) relates to ERG motivation theory, stating there are at least three things in the categories of individual needs, namely existence, connectedness, and growth. An explanation of the theory is as follows:

1. The need for existence is related to the fulfillment of survival needs, namely physical needs. 
2. These connectedness needs are related to the need to relate and interact with others

3. Meanwhile, growth needs are needs related to self-development to be productive and creative.

\section{Work Discipline}

Discipline is a matter that has an important function in human resource management, because the better employee discipline, the higher the performance results are achieved. According to Simamora (2006:610) discipline is a producer who corrects or punishes subordinates for violating rules or procedures.

Furthermore Wirawan in Masasti Suci and Ismiyati (2015) said that performance is influenced by one of the internal factors of the employee namely work discipline. Furthermore, Rivai (2011:825) states that there are at least four basic perspectives concerning work discipline namely, as follows:

1. Retributive Discipline

The application of discipline that tends to be done by the leadership by giving penalties for those who break the rules.

2. Corrective Discipline

The application of discipline by the leader tends to provide corrections and help employees to improve their attitudes and actions that are not in accordance with the rules.

3. Perspective of individual rights

The application of discipline tends to be carried out by the leadership by paying attention to the basic rights of each individual employee.

4. Utilitarian Perspective

The application of the discipline carried out by the leadership is a balanced enforcement effort with the impact done by individuals.

\section{Work Performance}

Good performance is an action to achieve the objectives of the organization so that efforts are needed to improve performance. Hasibuan (2007:105) states that performance is the result of work achieved by someone in carrying out work tasks given to him.

In more detail Mathis and Jackson (2010:324) set the main standards in measuring employee performance, which are as follows:

1. Output Quantity

Performance measurement that tends to be done by the leader by looking at the number of tasks that can be completed by employees.

2. Output quality

Performance measurement carried out by the leadership by looking at the accuracy and quality of the work carried out by its employees.

3. Output time

Performance measurement carried out by the leadership of employees by looking at the ability to complete tasks within the given deadline.

4. Level of attendance 
This performance measurement assesses employees from the frequency of employee attendance on weekdays.

5. Work efficiency.

This performance measurement pays attention to employees in terms of the ability of effective resource management in carrying out their duties.

\section{RESEARCH METHODS}

This type of research uses explanatory research with a quantitative approach with multiple linear regression data analysis techniques. The study was conducted at the Merangin District Settlement Area Office employees located on J1. Work Shop Kelurahan Pematang Kandis, Bangko sub-district, Merangin District, Jambi Province, Indonesia.

The sample of this research is the employees of the Merangin Regency Resettlement Area Office, totaling 80 employees. Data obtained by distributing questionnaires using a Likert scale and several documents from the official data. A questionnaire trial was given to 30 people outside the research sample. Based on the results of the questionnaire trial, 28 items were declared valid from a total of 32 questionnaire items with a calculated $r$ value $\geq r$ table (0.361) and at the same time the 28 questionnaire items were also declared reliable.

\section{FINDINGS AND DISCUSSION}

\section{Multiple Linear Regression Analysis}

Research data were analyzed using multiple linear regression analysis models. This is because there are two independent variables, namely work motivation and work discipline. Based on the results of testing using SPSS (21), the results of the equation of dressing liner regrets are as follows:

$\mathrm{Y}=79.21+0.41 \mathrm{X} 1+0.74 \mathrm{X} 2+\mathrm{e}$

From the test results it can be explained that the regression coefficient of motivation (X1) of 0.41 . This means that this variable has a positive effect on performance where if the Motivation variable is increased by one unit assuming the other variables are constant, then the performance of the Merangin Regency Settlement Area Office employees will increase amounted to 0.41. Conversely, if motivation decreases, there will be a decrease in performance.

Furthermore, from the test results it is known that the work discipline regression coefficient (X2) is 0.74 . It means that this variable has a positive effect on performance. Where if the Motivation variable is increased by one unit assuming the other variables are constant, then the performance of the Merangin Regency Settlement Area Office employees will increase by 0.74 . Conversely, if discipline decreases there will also be a decrease in performance

\section{Coefficient of Determination $\left(\mathbf{R}^{2}\right)$}

Based on the test results it is known that $\mathrm{R}$ is 0.58 . This shows that the correlation between the Performance variable and the Motivation and Discipline variable is a moderate level. Meanwhile, the coefficient of determination $\left(\mathrm{R}^{2}\right)$ is $0.34 \%$. This means that $34 \%$ of the variation in performance can be predicted by motivation and work discipline variables. While $65 \%$ can be predicted by other variables. 


\section{T Test (Partial)}

Based on partial tests it is known that $t$ count $\geq t$ table or $3.31 \geq 1.99$ with a significance level of $0.01 \leq 0.05$. This means that work motivation has a significant effect on the performance of Merangin Regency Settlement Area Office employees.

Meanwhile, based on other partial test results it is known that $t$ count $\geq t$ table or $5.02 \geq$ 1.99 with a significance level of $0.00 \leq 0.05$. This means that work discipline has a significant effect on the performance of the Merangin Regency Settlement Area Office employees.

\section{F Test (Simultaneous)}

Meanwhile, from the test results it is also known that the Fcount value is $20.17 \geq$ Ftable with a significance level of $0.000 \leq 0.005$. This means that the Motivation and Discipline variables simultaneously have a significant and significant effect on the performance variables of the Merangin Regency Settlement Area Office employees.

The results of this study are also supported by one of the previous studies, namely Annisa Pratiwi and Ismi Darmastuti (2014). On another occasion, Rivai (2011) argues that basically motivation can spur employees to work hard so that they can achieve their goals, thereby increasing employee performance so that it affects the achievement of company goals. This means that any increase in employee motivation will provide a significant increase in improving employee performance in carrying out their work.

\section{CONCLUSION AND SUGGESTION}

Based on the result of the research and analysis that has been doen to employees of Merangin Disctrict Settlement Area Office, can be concluded as follows:

1. Work motivation has a significant effect on the performance of Merangin Regency Settlement Area Office employees.

2. Work discipline has a significant effect on the performance of Merangin Regency Settlement Area Office employees.

3. Work motivation and work discipline have a significant effect on the performance of Merangin Regency Settlement Area Office employees.

Suggestion after doing the research, will be adressed to, as follow:

1. Merangin Disctrict Settlement Area Office, it is expected to be able maintain and increase employee motivation.

2. Merangin Disctrict Settlement Area Office, it is expected to emphasize the importance of employee discipline in order to be able to accomplish work that is in line with existing standards.

3. Next researcher, it is expected to be able to use it as a reference in doing next further reserach, more in-depth and comprehensive one.

\section{REFERENCE}

Adi Wahyudi, dkk. 2012. Pengaruh Disiplin Kerja, Motivasi Kerja, Dan Supervisi Kepala Sekolah Terhadap Kinerja Guru. Economic Education Analysis Journal. Vol 1 (2) pp:1-7.

Annisa Pratiwi dan Ismi Darmastuti. 2014. Pengaruh Motivasi Dan Disiplin Keja Pegawai Terhadap Kinerja Pegawai. Diponegoro Journal of Management. Vol 01 (01) pp:1-13 
Hasibuan, Malayu S. P. 2007. Organisasi dan Motivasi Dasar Peningkatan Produktivitas. BumiAksara: Jakarta.

Masasti dan Ismiyati. 2015. Pengaruh Displin Kerja, Motivasi Kerja Dan Tata Ruang Kantor Terjadap Kinerja Pegawai Kelurahan Kecamatan Purbalingga. Economic Education analysis journal. Vol 4 (3) pp: 706-719.

Mathis, L. R. dan J. H. Jackson. 2010. Human Resource Management.13 ${ }^{\text {th }}$ Edition. Sout Western College Publishing: Ohio.

Rivai, Veithzal. 2011. Manajemen Sumber Daya Manusia untuk Perusahaan. Edisi Kedua. Raja Grafindo Persada: Jakarta. 